\title{
超音速気流変動特性に及ぼす湿度効果について*1 Humidity Effects on Unsteady Characteristics of Supersonic Flow
}

\author{
高木正平*2 · 上村卓 也*2.平田裕 ${ }^{* 2}$ ·高田晃 輔*2 \\ Shohei TAKAGi, Takuya Uemura, Yutaka Hirata and Kosuke TAKAdA
}

Key Words : Supersonic Flow, Humidity, Condensation Shock Wave, Free-Stream Property

\begin{abstract}
Humidity in working fluid affects on supersonic flow properties. The paper is to evaluate the flow quality of the indraft supersonic wind tunnel of Muroran Institute of Technology against moisture. The static pressure fluctuation is measured by means of an unsteady pressure sensor buried in the model of 10 degree aperture cone model installed in the test section. Results show that supersonic flow at Mach 2 is contaminated by self-sustained oscillation of condensation shock wave in case of relative humidity more than approximately $50 \%$. It is also shown that staticpressure fluctuation to the dynamic pressure below a critical point with an absolute humidity $2\left[\mathrm{~g} / \mathrm{cm}^{3}\right]$ is attained below $0.1 \%$ in Mach 2 flow. Under atmospheric conditions between absolute humidity $2\left[\mathrm{~g} / \mathrm{cm}^{3}\right]$ and $6\left[\mathrm{~g} / \mathrm{cm}^{3}\right]$, static-pressure fluctuations may increase in the frequency range of $1-30[\mathrm{kHz}]$ due to phase change of minute ice particles generated in the supersonic nozzle. Experimental observations on three-dimensional boundary-layer transition hypersensitive to free-stream humidity are exemplified.
\end{abstract}

\section{1. は じめ に}

大気吸込み式超音速風洞における主流の気流特性は, 大 気に含まれる水蒸気の影響を受ける。湿度の高い空気が急 激に膨張した場合, 露点温度以下に達しても凝縮しないで 過飽和の状態となる。しかし, 何らかの原因で微小な液滴 が生成されると, やがて均一な凝縮が起こる. 超音速ノズ ル内で凝縮が発生すると流れに潜熱が放出されて, その放 出量が大きい場合にはノズル内で周期的な振動が誘起され る. その自励振動の発生機構はルートビーク管を用いた実 験的研究から, ほぼ解明されている1,2)。凝縮による潜熱の 発生により，ピトー管あるいは静圧管を用いた Mach 数計 測にも影響を及ぼすことが指摘されている ${ }^{3 \sim 5)}$ 。遷音速粘 性流れでは, 凝縮衝撃波発生のため翼の揚抗比が相対湿度 の増加とともに減少することが, 数值計算で明示されてい $ろ^{6)}$.

室蘭工業大学の中型超音速風洞は大気吸込み式の間欠風 洞で，測定部上流の流路内に調圧弁など流れを乱す突起が ないことから, 加圧式風洞に比べて気流変動は格段に小さ いことが期待される。しかし, 大気湿度が新たな気流変動 源になり得ることから, 今後予定されている境界層遷移研 究を初めとして各種試験研究に向けて, 大気湿度に対する 気流変動の相関関係を予め把握しておくことが求められて いる.

\footnotetext{
*1 (C) 2014 日本航空宇宙学会

平成 24 年 7 月 6 日, 第 44 回流体力学講演会/航空宇宙数値シ ミュレーション技術シンポジウム 2012 に扔いて発表. 平成 25 年 6 月 10 日原稿受付

$* 2$ 室蘭工業大学航空宇宙機システム研究センター
}

そこで, 本研究は, 大気圧, 湿度及び気温といった大気情 報をパラメータとして, 湿度に対する主流の気流変動評価 を行うことを目的としている．測定部主流の気流を評価す るために, 10 度円錐模型に埋め込んだ非定常圧力センサー を用いて静圧変動を計測する。 また測定部の凝縮濃度は主 流直角に微小径のレーザー光を透過させ, 凝縮によるレー ザー光の散乱による受光特性から評価する。境界層遷移は 主流変動に極めて敏感であることは周知である。たとえば, 三次元境界層を層流から乱流に導く横流れ不安定から, 定 在モードと進行波モードの 2 種類が成長するが7), 特に前 者は気流変動に敏感7 9) であることから, この性質を利用 して気流変動のレベルを示す指標とする。そのために後退 円柱表面に発達する三次元境界層の遷移過程で成長する横 流れ定在モードを可視化した結果も併せて報告する.

\section{2. 実 験 装 置}

2.1 超音速風洞 室蘭工業大学の中型超音速風洞の測 定部として，3つのノズルブロックが用意され，マッハ数 2,3 及び 4 に固定した超音速流が実現できる.いずれのブ ロックも長さは $2[\mathrm{~m}]$ で, 上下内面を曲面とした二次元ノズ ルであり，測定部断面は $400[\mathrm{~mm}] \times 400[\mathrm{~mm}]$ である．左 右の側壁には直径 $380[\mathrm{~mm}]$ のシュリーレン写真用の円形 ガラスが填め込まれている. 本研究ではマッハ数 2 のノズ ルブロックを用いた実験を行う。

気流は建物の外部に設置した外径 $1[\mathrm{~m}]$ の円形ベルマウ スで取り达み, 途中安全弁の下流には円形から正方形の変 形流路でノズルブロックに接続する。 ノズルブロック下流 には模型固定用の支持装置, その下流には流れを制御する スタート弁が設置され, 通風時に開弁される. 流路の最下 
流には容量が $100 \mathrm{~m}^{3}$ の真空タンクが 5 基設置され，通風 時間は 12 秒前後である。下流部の真空タンクを除く風洞外 形は既報文献 10)，11）に揭載されているので参照されたい.

2.2 凝縮濃度計測と絶対湿度の算出 大気湿度が高けれ ば超音速ノズルで水蒸気の凝縮が発生し, 気流は白濁し目 視でも十分確認できる場合もある。このような凝縮した微 小な水の粒は光を散乱することから, 測定部の外部から主流 直角に中心波長が $650[\mathrm{~nm}]$ の講演用赤色レーザーポインタ 光を放射し，その透過光を浜松ホトニックス社の $970[\mathrm{~nm}]$ に最大感度をもつシリコン系 PIN フォトダイオード $\mathrm{S} 6775$ で受光することで, レーザー光の減衰率から凝縮濃度の評 価が可能となる. なお, レーザー光の波長とフォトダイオー ドの最大感度をもつ波長と隔たりがあるが, 赤色レーザー光 に対しても十分な感度があることを事前に確認済みである。 また, 大気の湿度が高い場合には, 超音速スロート近傍で 自励的な凝縮衝撃波の発生から変動が生ずることが知られ ていることから, ダイオード出力の時間変動にも着目した. さらに，この時間変動の位相を主流方向に追跡できれば，流 れ方向に設置したフォトダイオードの間隔と受光信号の位 相差から, 凝縮変動の移流速度を評価できるはずである。こ の推測に基ついて, 第 1 図に示すようにレーザー光と受光 ダイオードを組み合わせた 5 組を主流方向に $45[\mathrm{~mm}]$ 間隔 で並べ, ダイオード出力信号を同時計測した。この変動の周 波数は $1[\mathrm{kHz}]$ 以下であることから, 各信号を後述する $\mathrm{NF}$ ブロック社製のデータロガーEZ7510を用いて $100[\mathrm{kHz}]$ ないしは $200[\mathrm{kHz}]$ で同時収録した.

大気の相対湿度 $[\%]$ から絶対湿度 $\left[\mathrm{g} / \mathrm{m}^{3}\right]$ の換算は, 文 献 12) を参照した。換算式を以下に示す.

絶対湿度=相対湿度 $[\%] \times 0.794 \times 10^{-2} \times \exp (e) / 100$,

ここに

$$
\begin{aligned}
e= & -(6096.9385 / T+21.2409642 \\
& -2.711193 \times 10^{-2} \times T+1.673952 \times 10^{-5} \times T^{2} \\
& +2.433502 \times \log (T)) /(1+0.00366 \times t),
\end{aligned}
$$

であり, $e$ は水蒸気圧 $[\mathrm{Pa}], T$ は絶対温度 $T[\mathrm{~K}]=273.15+$

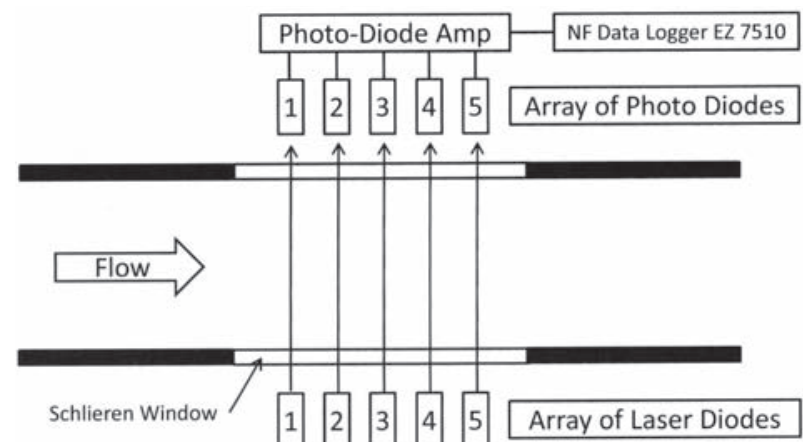

第 1 図 マッハ数 2 の超音速ノズル測定部下流方向に水平に $45[\mathrm{~mm}]$ 間隔で並べた 5 組のレーザーダイオードとフォトダイオード $t, t$ は乾球温度 $\left[{ }^{\circ} \mathrm{C}\right]$ である.

なお，以降絶対湿度と相対湿度をそれぞれ $\mathrm{AH}$ と $\mathrm{RH}$ と 略記することとし，AH3.1 は絶対湿度 $3.1\left[\mathrm{~g} / \mathrm{m}^{3}\right]$, RH50 は相対湿度 50[\%] を意味する。

2.310 度円錐模型と非定常圧カセンサー, 斜め円柱模 型 測定部内壁に発達している境界層はいずれのノズル ブロックでも乱流であり, 測定部気流の静圧変動評価に測 定部内壁の静圧変動計測からは評価できない. そこで, 静 圧変動計測のために 10 度円錐模型を新規製作した。模型 断面図を第 2 図 (a) に示す。円錐部の流れ方向の全長は $250[\mathrm{~mm}]$, 先端から $70[\mathrm{~mm}]$ まではステンレス鋼で先端半 径は $0.14[\mathrm{~mm}]$ である. その先端部下流端より断熱材として 広く知られた金属より熱電導率が低いベスペル®材で製作し た. 先端金属部表面の中心線平均粗さ $(\mathrm{Ra})$ は, $0.21 \mu \mathrm{mRa}$, ベスペル製の下流部は $0.2 \mu \mathrm{mRa}$ であり，先端と下流部の 接合部の段差は $5 \mu \mathrm{m}$ 以下に仕上げられている。 Kulite 製 の差動型半導体圧力センサー XCQ-62-350 mBARD（感度 $5[\mathrm{PSI}]=34.5[\mathrm{kPa}])$ を直径 $0.5[\mathrm{~mm}]$ の静圧孔の下に埋め 込んだ. 圧力センサーの外径は $1.65 \mathrm{~mm}$ であり模型表面直 角に，また模型表面とセンサー上面との間隔は約 $0.5[\mathrm{~mm}]$ である。このように圧力センサー面と模型表面までの間隔を 狭め, さらに静圧孔とセンサー上面の空隙容量を小さくする ことでヘルムホルツ共振周波数を圧力センサーの応答特性 より高めた。静圧孔の位置は，円錐模型先端より $120[\mathrm{~mm}]$ である。

計測した静圧変動の実効值を算出する手順として, 通風 中の全データを印刷し, 通風時間内の緩やかな変化が観測 された場合には，その増加減少分を除去した，動圧に対す る静圧変動レベルの 10 度円錐模型境界層遷移に関するデー タベース ${ }^{13)}$ によると, 変動レベルが $0.1 〜 0.3[\%]$ の環境で は遷移レイノルズ数はそれぞれ約 $5 \times 10^{6} \sim 6 \times 10^{6}$ と予測さ れている. 非定常圧力七ンサー位置におけるレイノルズ数

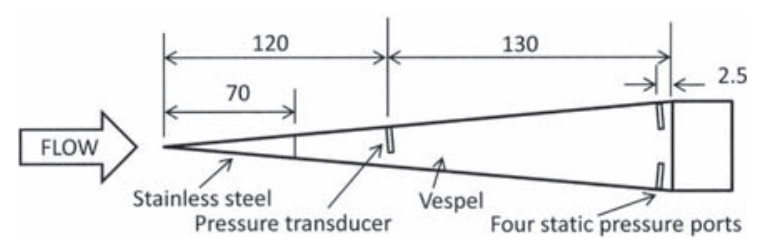

(a)

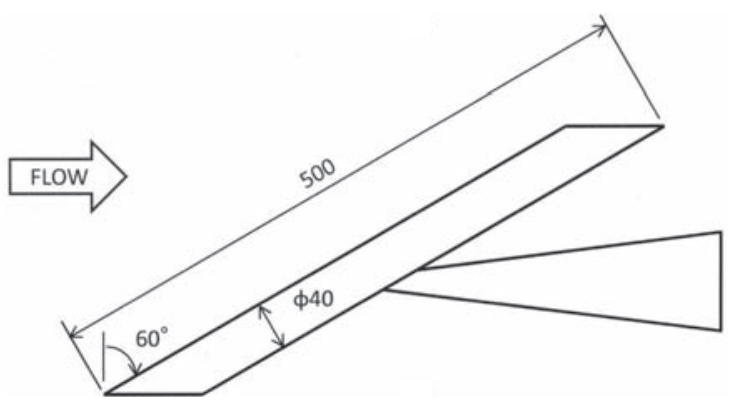

(b)

第 2 図 風洞模型

(a) 10 度円錐模型，（b）斜め円柱模型．単位は [mm]. 
は約 $0.8 \times 10^{6}$ であることから層流は維持されているものと 推察される. Kulite 製のセンサーカタログによると, 応答 特性は共振周波数 $150 \mathrm{kHz}$ の $20[\%]$ が目安となるので, 非 定常変動に対する応答限界は $30[\mathrm{kHz}]$ 程度である。 このセ ンサーアンプとして, 共和電業の直流増幅器 CDV-700A を 用いた. 円錐模型の先端より $245[\mathrm{~mm}]$ には周方向 $90\left[^{\circ}\right]$ 間 隔に 4 箇所静圧孔を空けてあり, 主流に対する迎え角 $0\left[^{\circ}\right]$ の微調整に用いた。

三次元境界層遷移の試験には, 第 2 図 (b) に示すように ステンレス製の直径 $40[\mathrm{~mm}]$, 軸長 $500[\mathrm{~mm}]$ の円柱模型 を主流に対して $60\left[^{\circ}\right]$ の後退角をもたせ, 中央部を保持し て鉛直面内に設置した。模型先端と後端はいずれも流れに 対して平行に切り落とした。横流れ不安定に起因して成長 する定在モードの縦渦列はオイルフロー法を用いて円柱表 面の可視化を行った。 オイルフローで使用した材料は, 酸 化チタン, オレイン酸, 流動パラフィンで $1: 2: 8$ の割合 で混合した。通風中にはビデオカメラで, また通風後は静 止画像を取得した。

2.4 データ収録と解析 デー夕収録装置として NF ブ ロック社の EZ7510 を用いた。 この装置の入力部であるア ナログ信号からデジタル信号に変換する入力ポートは 8 チャ ネル, 各ポートは 16 ビットの分解能をもち, 最高サンプ リング周波数は $1[\mathrm{MHz}]$ である. 本実験では, サンプリン グ周波数を $100[\mathrm{kHz}]$ ないしは $200[\mathrm{kHz}]$ とした. EZ7510 の前段には，日本オーデオ社製の減衰特性 100 [dB/Oct $]$ の ローパスフィルターPGF-8 を設置し, 遮断周波数はサン プリング周波数の 0.5 倍とした。収録された非定常圧力セ ンサー出力とフォトダイオード出力は, エクセルないしは Matlab を用いて周波数分析ならびに解析結果のプロット を行った。

\section{3. 実 験 結 果}

3.1 水蒸気凝縮の定量評価 測定部の超音速流を透過し フォトダイオードで受光した信号は, 超音速流が起動する時 刻を挟んで，直流成分からデーターロガーに収録した。第 3 図 (a) は代表的な 4 通りの条件，すなわち(AH2.9, RH52), (AH5.0, RH44), (AH6.6, RH52) および (AH8.9, RH78) について, 受光波形の時系列デー夕を比較したものである. 見やすくするために, 受光の強度を示す縦軸は各信号に適 当な係数をかけてあるので, 波形間の強度の比較は無意味 である。また各波形の時間軸（横軸）も適当にずらしてあ る. 風洞起動前の各信号の電圧值は一定值を示しているが, いずれの波形についてもある時点で急激に出力の低下が観 測される。この時刻が通風の開始時刻に対応している。レー ザー光が完全に散乱されると出力は $0[\mathrm{~V}]$ であることから, いずれのケースも起動時瞬時ではあるが, 完全散乱が生じ ていることを示している，このような透過光の変化は，風 路内の空気に含まれる水蒸気の凝縮による水の粒子でレー ザー光が完全散乱されたためである。なお, 湿度が (AH6.6, RH52）のケースでは，通風前後を通して振幅の小さな周 期変動が重畳しているが, 計測時風洞の照明を消さなかっ
たために照明の強度変化をとらえたものである.

透過光特性は湿度の大きさに応じて 2 種類に分類できそ うである。すなわち, 絶対湿度が AH6.6より小さい場合 には, 起動直後の過渡的変化の後 0.4 [秒] 以内で出力の変 動も小さくほぼ一定となった。しかし, 湿度が最も大きい AH8.9 のケースでは, 通風後の波形の振幅が大きいことが 分かる。この波形の時間軸を拡大して示したのが, 第 3 図 (b)である。規則的でほぼ一定振幅の周期変動がとらえら れ, その周波数は $225[\mathrm{~Hz}]$ であった。通風前の透過光の強 度を $100[\%]$ とすると, 第 3 図 (a) から通風時透過光の平 均值は約 48[\%] まで減少し, 変動の両振幅も約 65[\%] に達 し極めて大きな周期変動であることが理解できる。 この周 期変動の由来は, 大気の湿度が大きい場合, 大気が超音速 スロートを通過する際に起こる凝縮衝撃波の発生に伴う自 励振動であることは，すでに松尾ら ${ }^{1,2)}$ が指摘している通 りである。前掲の第 3 図 (b) あるいは第 5 図 (c) で後述す るように, 振動周波数の高い選択性は, 松尾らが指摘した 自励振動の特徵を示唆している.

ここには示していないが, 絶対湿度が AH1.9のケースで は起動直後の過渡的な変化を除外すれば, 受光器の出力変 化はほとんど観測されなかった。第 3 図 (c) には通風前の 受光器の出力に対して, 通風中の直流成分の減衰量を絶対 湿度に対して図示したもので, 直線は最小自乗法で求めた ものである，絶対湿度が減少すると透過光はほぼ直線的な 増加傾向を示している。 すなわち, 絶対湿度が AH18より 大きくなるとレーザー光は測定部を透過しない程度に凝縮 しているが, 絶対湿度が AH2 以下では透過光の減衰はほと んど見られないことを示している。一方, 凝縮衝撃波の発 生に起因する周期変動の周波数を絶対湿度及び相対湿度に 対して整理したのがそれぞれ第 3 図 (d) と (e) である。絶 対湿度に対する変動周波数の相関関係は小さいが, 相対湿 度で整理すると変動周波数は 1 つの関係式で整理できそう である。そこで第 3 図 (e) には松尾ら ${ }^{1)}$ が次元解析と彼ら の実験結果から導出した相関式もプロットしてある. なお, 松尾らの相関式によれば衝撃波の振動周波数は相対湿度 $\phi$ の 1.76 乗と総温の 0.5 乗の積に比例して高くなることを示 しているが, 本データの総温変化の幅は小さいため, 総温 に関する依存性については議論できない.しかし，本実験 結果は松尾らの相関式とよく一致していることが分かる.

凝縮衝撃波の自励振動に伴って生じている凝縮濃度の流 れ方向の移流速度を計測するために，流れ方向に $45[\mathrm{~mm}]$ 間隔で並ベたレーザー光とその受光器の 5 セットから得ら れた時系列デー夕を第 4 図に示す。時系列デー夕は前掲第 3 図 (a) の絶対湿度が最も高い（AH8.9, RH78）流れの条 件で取得したものである. 受光器出力の感度はセンサーご とに異なることから, 位相比較のために振幅をそろえて図 示してある. 上流から番号付けされた受光器出力は下流方 向に位相が遅れている様子がとらえられている。各信号間 の位相遅れは, 相互相関から算出した。 その結果, 最上流と 最下流の位相差は, 間隔 $180[\mathrm{~mm}]$ に対して $0.356[\mathrm{~ms}]$ で あったことから位相速度は $505[\mathrm{~m} / \mathrm{s}]$ と求まる。総圧管圧力 


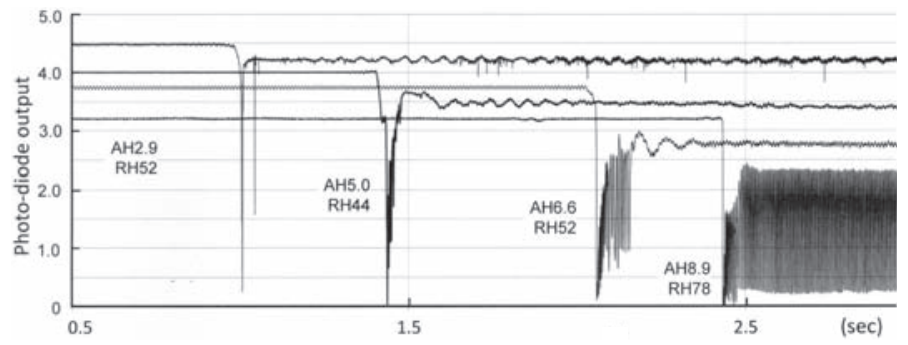

(a)

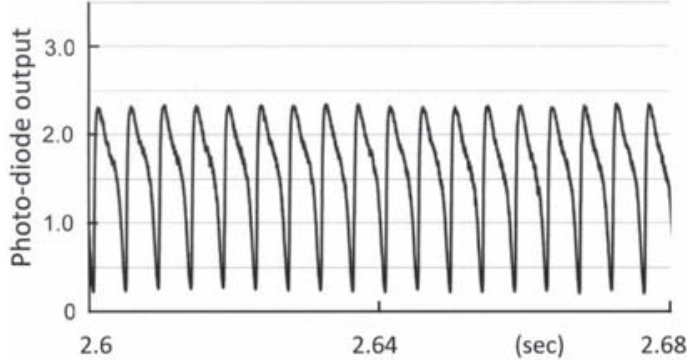

(b)

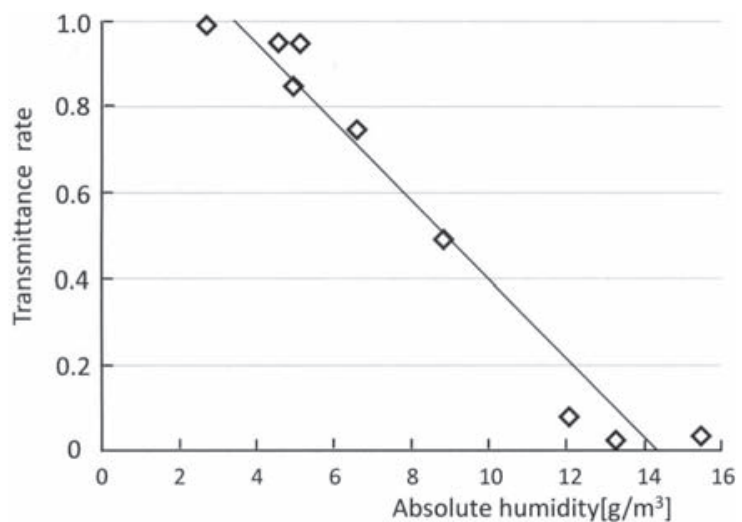

(c)

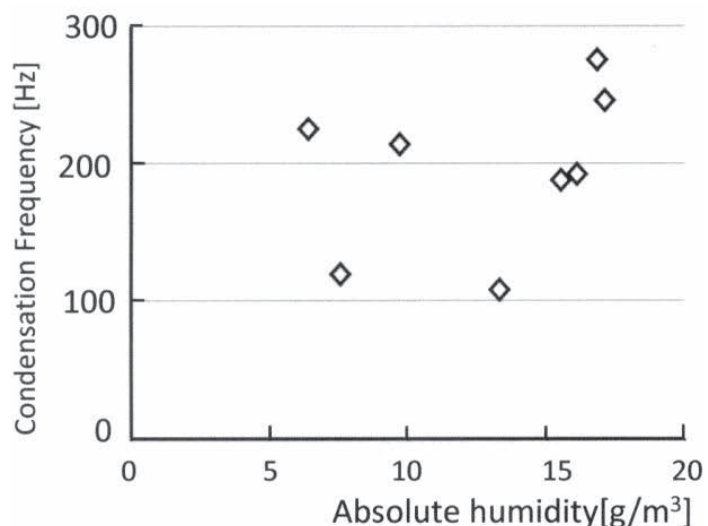

(d)

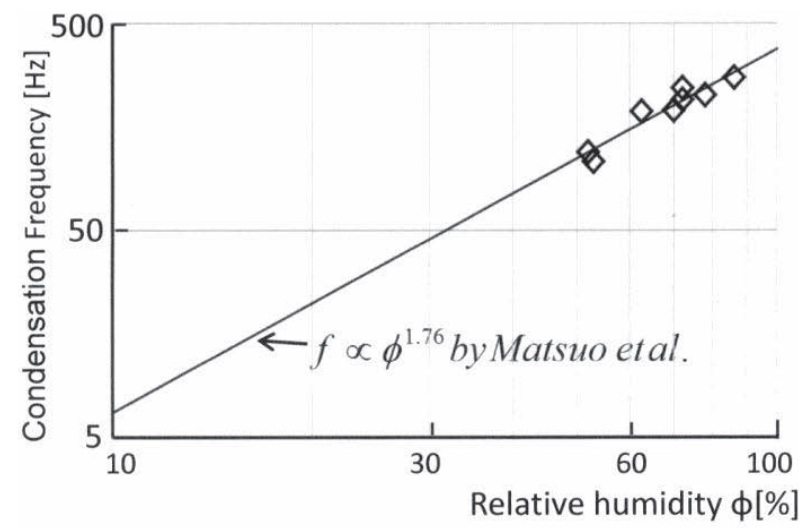

(e)

第 3 図＼cjkstart湿度に対する通風前後の透過光の特性

(a) 出力信号の比較，(b) AH8.9 の条件における出力信号の時間軸拡大，(c) 絶対湿度に対するレーザー光の透過率，(d) 絶対湿度に対 する凝縮振動周波数, (e) 相対湿度に対する凝縮振動周波数.

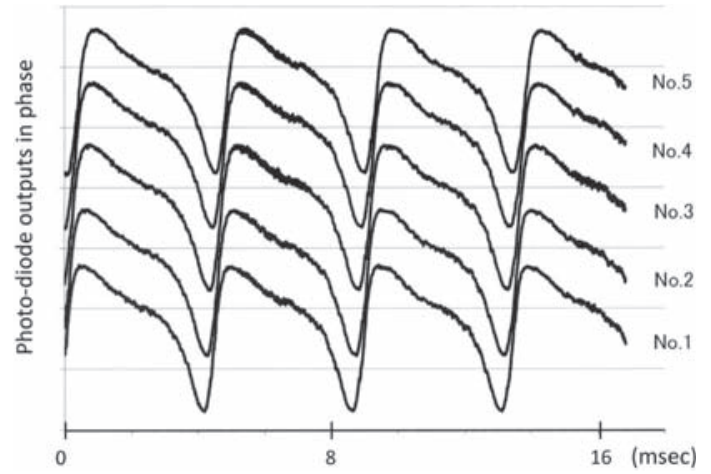

第 4 図 透過光の同時計測結果
から等エントロピ関係式を用いて求めた主流速度 $507[\mathrm{~m} / \mathrm{s}]$ と同程度であることが分かった，総圧管の読みも湿度の影 響を受けるが，氷の微粒子はほとんど滑ることなく主流に 乗って流下していると考えられる.

3.2 円錐模型の静圧変動 湿度が高い場合には水蒸気 の凝縮は時間的な変動を伴うことから，この効果は測定部 の気流特性に何らかの影響を及ぼすことが懸念される。そ こで，10 度円錐模型の非定常圧力七ンサーを用いた静圧変 動の計測結果を次に示す。

湿度が異なる代表的な 4 通りの条件下で，円錐模型の非 定常圧力センサーで計測した静圧変動波形を第 5 図 (a) に, またこれらの波形を周波数分析した結果を第 5 図 (b) に比 較している。第 5 図 (a) も (b) も見やすくするために, 変 


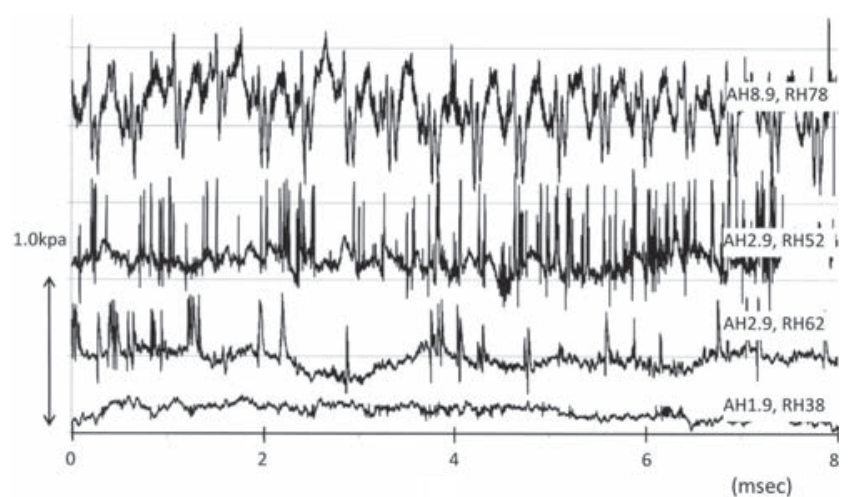

(a)

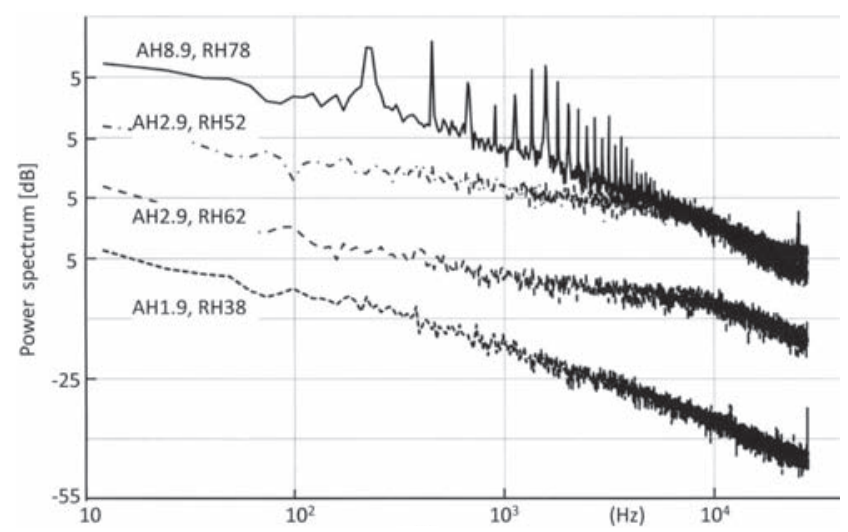

(b)

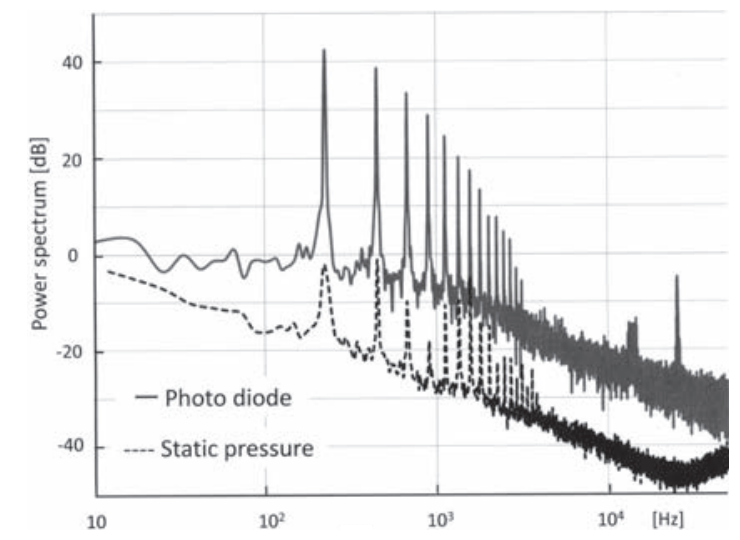

(c)

第 5 図 絶対湿度に対する 10 度円錐模型の, (a) 静圧変動波形の比 較, (b) 静圧変動のパワースペクトルの比較, (c) 静圧変動と 透過光波形のパワースペクトルの比較

動波形の平均值はずらしてプロットしてあり，波形の振幅 は相対比較できるが，平均值の比較は無意味である。また 湿度条件（AH1.9, RH38）で計測したスペクトルを基準に 各スペクトルは $+15[\mathrm{~dB}]$ のオフセットをつけて図示して ある. 最も絶対湿度の高い条件（AH8.9, RH78）における 静圧変動は, すでに掲載した第 3 図に示したレーザー受光 器出力と同時に取得したものである.

湿度が異なる 4 ケースの中で絶対湿度と相対湿度が最も 低いケース（AH1.9， RH38）の条件下における静圧変動 は, 予測される通り波形観測からも変動の振幅が最も小さ い.この結果はスペクトル解析結果とも整合しており, 全周
波数帯域に渡って特徵的な変動成分もなく，周波数の増加 とともに変動振幅もなだらかに減少し, その全変動の実効 值は後述するように主流の動圧に対して $0.1[\%]$ 以下である. 一方, 絶対湿度が最も高いAH8.9 の条件においては, 静圧 変動に周期的な波形が観測され, 変動の全振幅は $1[\mathrm{kPa}]$ 弱 で総圧のほぼ $[\%]$ に達していることが分かる。また, この 波形を周波数解析したスペクトル分布には鋭いピーク状の 成分が観測され，その基本波の周波数は $225[\mathrm{~Hz}]$ である. この周波数は, 前掲した第 3 図 (b) のレーザー受光器出力 変動の周波数と同じであることから, 凝縮に伴う自励振動 が測定部の静圧に直接影響を及ぼしていることが明らかと なった．確認のために，レーザー受光器出力変動のスペク トルと静圧変動のスペクトルを第 5 図 (c) に比較した。両 者の周期変動成分は高調波成分も含めて極めて強い相関が 確認できる。また, 興味深い点は, この自励振動に起因す る離散的な基本周波数成分及びその高調波成分以外の静圧 変動の連続成分は, 絶対湿度が本実験の中で最も低いケー ス (AH1.9, RH38) の静圧変動のレベルとほとんど差異 は見られないことである。このことは, 第 3 図 (b) のレー ザー透過光の変動に不規則変動がほとんど重畳していない 事実からも推測できる.

一方，第 5 図 (b) において自励振動が観察されていない 2 つのケース $(\mathrm{AH} 2.9, \mathrm{RH} 52)$ と $(\mathrm{AH} 2.9, \mathrm{RH} 62)$ におい て, 前者については第 3 図 (a) で絶対湿度が小さい例とし てレーザー受光器の出力波形を示した。 この前者の条件で はレーザー光の減衰は $5[\%]$ 程度, 後者の条件では減衰はほ とんどなく, 目視による気流の白濁はいずれの場合も観察 されていない. しかし, この 2 つのケースの静圧変動に共 通していることは, 第 5 図 (a) に示すように正のパルス状 の静圧変動が不規則に重畳していることで, パルス状の変 動の頻度は, 相対湿度が低い方がむしろ高い. 第 5 図に示 したスペクトル分布を比較すると, 絶対湿度が本実験の中 で最も低いケース（AH1.9， RH38）に比べて 1〜30 [kHz] 带域で変動レベルが相対的に高いことは明白である。これ らのパルス状の変動が $1 \sim 30[\mathrm{kHz}]$ 帯域の変動成分の増大 に貢献していると考えられる。パルス状信号の幅は, 0.25 〜 $0.5[\mathrm{~ms}]$ 程度であり, 円錐模型に沿うマッハ数は 1.9 であ ることから, パルス状信号の主流方向の空間スケールは 120 〜240 [mm]である.このような空間スケールをもつ変動源 として次の理由が考えられる。湿った空気が超音速ノズル を通過した際，凝縮によって作られた氷の粒子が，円錐模 型の先端に生じる衝撃波を通過する際, 水から水もしくは 水滴への相変化が生じ, 準一次元理論によると, この際吸 熱反応で相変化中の粒子は減速され, 結果として静圧の上 昇を伴うであろう。静圧孔付近をこのような相変化粒子が 通過することでパルス状の圧力上昇が発生すると推測され る。一方, 凝縮衝撃波の自励振動が生じる湿度が高い条件 では，振動の周期に同期して相変化が行われるために，1〜 $30[\mathrm{kHz}]$ 帯域の静圧変動は生じないものと考えられる。ま た, 前掲第 3 図 (a)の（AH2.9, RH52）の条件では, レー ザー受光器出力波形に時折下向きのパルス状信号がとらえ 


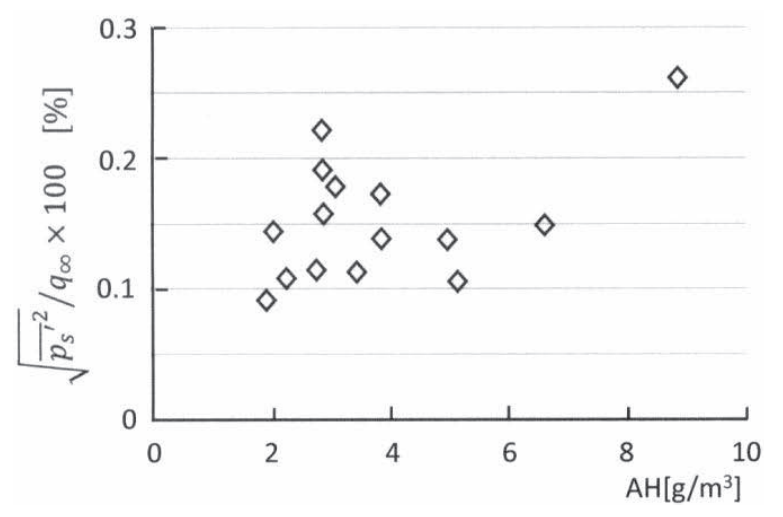

(a)

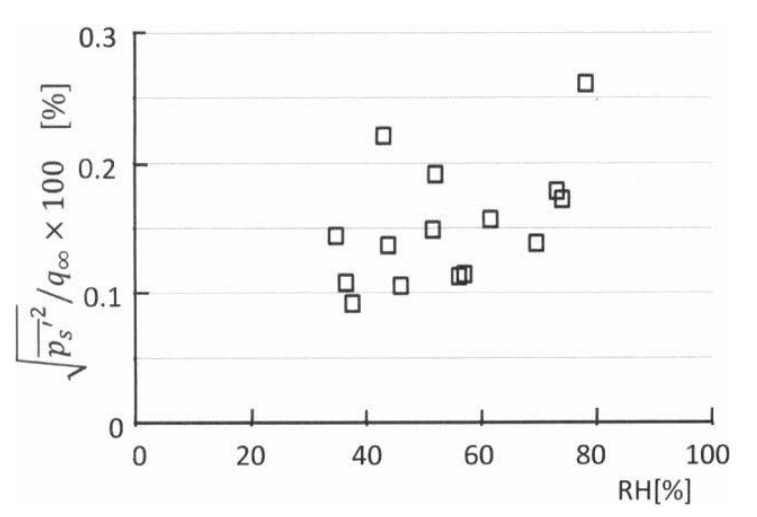

(b)

第 6 図 湿度に対する静圧変動強度の比較 (a) 絶対湿度に対する静圧変動強度, (b) 相対湿度に対する静圧変動強度.

られているが，これはある程度の空間スケールをもつ沓の 微粒子群がレーザー光を通過した結果であると推測される。 なお, 上記の正のパルス状静圧変動発生の機構に関する推 測を裏付けるために, 熱線あるいは冷線温度センサー等を 静圧孔近傍に設置し, 静圧と熱線風速計の出力の同時計測 による相関計測を予定している。

絶対湿度あるいは相対湿度に対して, 静圧変動の実効值 を動圧で無次元化した結果を第 6 図 (a) と (b) に示す. 絶 対湿度が低いほど，また相対湿度が低いほど静圧変動は小 さくなる傾向を示しているが, どちらの湿度に対しても強 い相関関係はない。 ただ, 室蘭地区の冬場では, AH2 以下 では気流変動レベルは $0.1[\%]$ 以下 ${ }^{14)}$ が達成されており, 超 音速流の静肃条件の目安となる気流が実現されている。こ のような大気湿度の影響が比較的小さい気流ならびに凝縮 振動が生じている湿度が大きい場合について, 境界層遷移 に関する比較実験を実施した。

3.3 斜め円柱境界層遷移 湿度条件 (AH2.6, RH56) の下でオイルフローによる円柱表面の可視化写真を第 7 図 (a)に示す. 円錐模型を用いた静圧変動計測を同時にはでき ないことから, 第 6 図から静圧変動の大きさを推定すると, 動圧に対して $0.1 〜 0.2 \%$ の範囲である。このような気象条 件の下で, 数回の通風で比較的明確な痕跡が確認できた可 視化像のうちの 1 枚である。横流れ不安定は粗さに敏感で あることから横流れ不安定の臨界点が存在する付着線近傍 領域ではオイル塗布は避け, 特に 30〜90 $\left[^{\circ}\right]$ の領域を可視 化した，写真上部には $1[\mathrm{~mm}]$ 単位のスケールと右側には 付着線から円柱表面の角度 $\phi\left[^{\circ}\right]$ を示す数字が映し込まれて いる. $\phi=40\left[^{\circ}\right]$ より下流から多数の筋状の痕跡が認められ る.そこで， $\phi=50\left[^{\circ}\right]$ に沿って画像に書き込んだ白線方向 （付着線に平行方向）に沿ってデジタル画像データをスペク トル解析することで波長 $\lambda$ を算出した（第 7 図 (b)). ス ペクトル解析から波長は約 $0.9[\mathrm{~mm}]$, 本実験条件で線形安 定解析から得られた波長は $0.82[\mathrm{~mm}]$ であることから, 概 ね両者の一致も確認され, 筋状の痕跡は横流れ不安定の定 在モードの存在を示唆するものと言えよう。また, $0.1[\%]$ 以下の静圧変動が達成されている条件下で熱線風速計によ

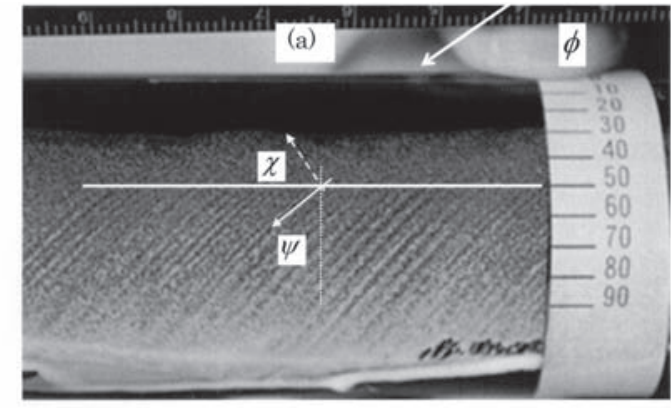

(b)

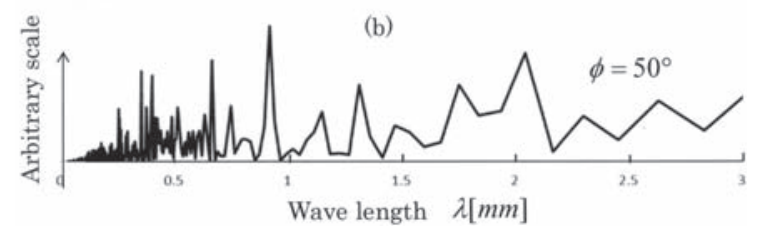

第 7 図 オイルフローによる通風終了時の円柱表面の可視化像 (a) と 波長計測 (b). 湿度条件 (AH2.6, RH52).

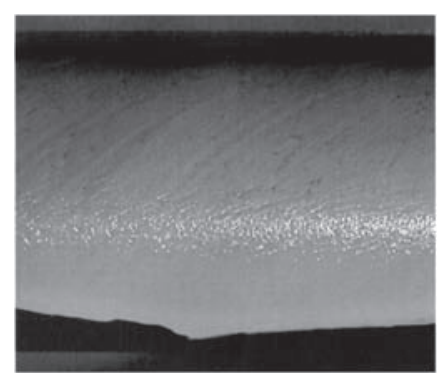

(a)

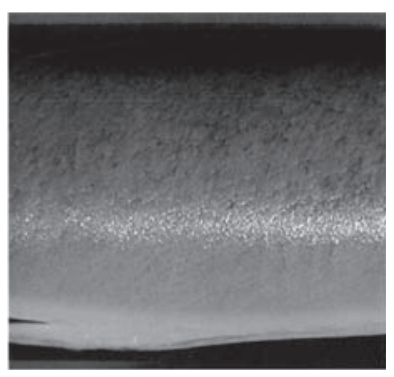

(b)
第 8 図 絶対湿度 $6.9\left[\mathrm{~g} / \mathrm{cm}^{3}\right]$ の条件における通風時の円柱表面の才 イルの挙動

(a) 通風開始 2 秒後, (b) 通風開始 6 秒後.

る時間発展型モードの検出も行い, 線形安定解析との比較 検証から横流れ進行波モードと同定された。詳細は別報15) を参照されたい. 一方，第 8 図に示すように相対湿度が高 く凝縮衝撃波が発生する条件（AH6.9）では通風開始時に は弱いながらも筋状の痕跡が確認されたが, 通風を停止す るまでの間に，殆どその痕跡は消滅した。この結果は，気 
流変動が大きい条件では, 三次元境界層の横流れ不安定に 起因する定在型モードは成長しにくいという Bippes ${ }^{8)}$ の 実験結果と整合しているように見える。しかし, 境界層遷 移は主流変動のレベルの大きさだけでなく, どの周波数帯 域の成分が遷移過程に係っているかなど, 今後の詳細な調 査が必要である。

\section{4. 結}

論

大気吸込み式超音速風洞は, 大気に含まれる水蒸気の凝 縮は避けられないため, 風洞気流特性は大気湿度の影響を 受ける。この影響を定量的に評価するために, 大気湿度に対 して測定部のマッハ数が 2 の超音速ノズルに 10 度円錐模型 を設置し, 模型内部に埋め込んだ非定常圧力センサーで静 圧変動を計測した。また, 測定部の超音速流に直角にレー ザー光を照射し, 透過レーザー光をシリコン系 PIN フォ トダイオードで検出し, 凝縮の定量評価を行った.さらに, 気流変動に敏感な三次元境界層遷移過程をオイルフローで 可視化することで気流の質の効果を例証する実験も行った. その結果，以下の結論が導ける.

1) 絶対湿度が概ね $2\left[\mathrm{~g} / \mathrm{m}^{3}\right]$ 以下では, 超音速流の動圧 に対する静圧の変動は $0.1[\%]$ 以下である。

2) 絶対湿度が $2 \sim 6\left[\mathrm{~g} / \mathrm{m}^{3}\right]$ の範囲では, 1〜30 [kHz] 带 域で静圧変動のレベルが相対的に増大するが，これは比較 的低周波の静圧変動に重畳する正のパルス状変動によるも ので，その空間スケールは 120～ $240[\mathrm{~mm}]$ 程度である.

3)この正のパルス状変動は超音速ノズルで生成された水 の粒子が円錐模型の先端の衝撃波を通過する際, 再び相変 化する際の吸熱反応に起因するものと考えられる。

4) 実験した範囲で, 絶対湿度が $6\left[\mathrm{~g} / \mathrm{m}^{3}\right]$ 以上, 相対湿 度が 50[\%] 以上で 90[\%] 以下では, 超音速ノズルで自励振 動を伴う凝縮衝撃波が発生する.

5) 凝縮による自励的振動の発生によって測定部にこの振 動周波数をもつ静圧变動を招来し, この静圧変動と凝縮変 動を検出するレーザー透過光強度と強い相関が観測された.

6) この凝縮変動は超音速流とともに移流している.

7) 絶対湿度が小さく, 気流変動が比較的小さな超音速流 に置かれた斜め円柱境界層には, 横流れ不安定に起因した 定在モード遷移が観察された。

8) 一方, 絶対湿度が高く凝縮衝撃波が形成された超音速 流では，定在モード遷移が観察されなかった。
斜め円柱表面に沿う超音速三次元境界層の安定解析は大 阪府立大学の坂上昇史先生にお願いした。深甚なる感謝の 意を表したい。また, データ取得・処理では, 室蘭工業大 学大学院生の大立目博幸君に多大なる協力を頂いた。 ここ に感謝を申し上げる。

\section{参 考 文 献}

1）松尾一泰，川越茂敏，園田圭介，瀬戸口俊明：凝縮を伴うラバル ノズル流れの振動（第 1 報，振動の発生範囲と周波数について）, 日本機械学会論文集（B 編）, 49 (1983),pp. 108-114.

2) 松尾一泰, 川越茂敏, 園田圭介, 瀬戸口俊明: 凝縮を伴うラバル ノズル流れの振動（第 2 報，振幅と発生機構について），日本機 械学会論文集（B 編）， 50 (1984), pp. 1319-1324.

3) Huang, J. C., Gault, R. I., Benard, E. and Raghunathan, S. Effect of Humidity on Transonic Flow, J. Aircraft, 45 (2008), pp. 2092-2099.

4) 永井伸治, 津田尚一, 小山忠勇, 平林則明 : 極超音速風洞の水分 管理，日本航空宇宙学会誌，55 (2007), pp. 483-489.

5) Herring, G. C.: Mach-Number Measurement with Laser and Pressure Probes in Humid Supersonic Flow, AIAA J., 46 (2008), pp. 2107-2108.

6) 入屋明広, 山本 悟, 大宮司久明：湿度を考慮した遷音速粘性 流れの数值解法, 日本機械学会論文集 (B 編), 62 (1996), pp. $3854-3859$.

7) Saric, S. W. and Reed, H. L.: Stability of Three-Dimensional Boundary Layers, Annu. Rev. Fluid Mech., 21 (1989), pp. 235-284.

8) Bippes, H.: Basic Experiments on Transition in ThreeDimensional Boundary Layers Dominated by Crossflow Instability, Progr. Aerospace Sci., 35 (1999), pp. 363-412.

9) Takagi, S. and Itoh, N.: Observation of Traveling Waves in the Three-Dimensional Boundary Layer Along a Yawed Cylinder, Fluid Dynamics Res., 12 (1994), pp. 167-189.

10) 湊亮二郎, 溝端一秀, 桑田耕明: 吸込み式超音速風洞におけるス ターティングロードの計測と供試体の挙動, 日本航空宇宙学会論 文集, 56 (2008), pp. 580-589.

11) Minato, R., Mizobata, K. and Kuwada, K.: Experimental Measurements of Starting Loads and Model Behaviors in the Indraft Supersonic Wind Tunnel, Trans. Jpn. Soc. Aeronaut. Space Sci., 53 (2010), pp. 54-62.

12) 第一科学の湿度計算式, http://www.daiichi-kagaku.co.jp/ situdo/notes/note108

13) Dougherty, N. S., Jr. and Fisher, D. F.: Boundary-Layer Transition on a 10-Deg Cone: Wind Tunnel/Flight Correlation, AIAA Paper 80-0154, 1980.

14) Wolf, S. W. D., Laub, J. A. and King, L. S.: Flow Characteristics of the NASA-Ames Laminar Flow Supersonic Wind Tunnel for Mach 1.6 Operation, AIAA Paper 94-2502, 1994.

15) Takagi, S., Sakaue, S., Hirata, Y., Uemura, T. and Takada, K.: Observation of Cross-Flow Instability Mode in a Yawed Cylinder Boundary Layer at Mach 2, AIAA J., in review. 